\title{
THE ROLE OF PHYSIOTHERAPY TREATMENT IN ARM LYMPHOEDEMA ASSOCIATED WITH BREAST CANCER
}

\author{
Mihnea Peter BORDEA ${ }^{1}$, Ruxandra EL-BSAT ${ }^{1 *}$, Aniela NODITI ${ }^{2,3}$, \\ Cristian BORDEA ${ }^{2,3}$
}

\footnotetext{
${ }^{1}$ National University of Physical Education and Sport, Faculty of Physical Therapy, Bucharest, Romania

2 "Carol Davila" University of Medicine and Pharmacy, Bucharest, Romania

3 "Prof. Dr. Al. Trestioreanu” Institute of Oncology, Bucharest, Romania

*Corresponding author: andabsat@yahoo.com
}

https://doi.org/10.35189/dpeskj.2021.60.4.5

\begin{abstract}
Ipsilateral arm lymphoedema is the most frequent long-term complication due to breast cancer surgery, chemo- and radiotherapy, affecting approximately $40 \%$ of women treated for this condition. We conducted a retrospective study to assess the efficiency of physiotherapy procedures in reducing arm lymphoedema in women who underwent an exhaustive treatment plan for breast cancer. The study included 32 patients out of the 641 with breast cancer, who were treated by the same multidisciplinary team at the "Prof. Dr. Alexandru Trestioreanu" Institute of Oncology in Bucharest. They underwent unilateral modified radical mastectomy with axillary clearance between 1 January 2016 and 31 December 2019 due to developing ipsilateral arm lymphoedema, stage 2. Of the 18 patients who received individual counselling and education, manual lymph drainage and compressive bandage, 10 (55.5\%) decreased arm lymphoedema from stage 2 to 1 after 3 months of treatment. Of the 14 patients who associated these procedures and also benefitted from additional individual physiotherapy including stretching exercises (for the levator scapulae, trapezius, pectoralis major and minor) and progressive active and action-assisted shoulder exercises, 11 (78.5\%) reduced arm lymphoedema to stage 1 and regained upper arm mobility and sensitivity. Early initiation of physiotherapy after modified radical mastectomy with axillary lymph node dissection, along with patient education, is associated with a higher regression rate of arm lymphoedema compared to only patient education and awareness. The treatment response rate was $85.7 \%$ in patients benefitting from lymphatic drainage, compressive bandage and an individual physiotherapy plan compared to $55.5 \%$ in patients only benefitting from lymphatic drainage and compressive bandage.
\end{abstract}

Keywords: physiotherapy, arm lymphoedema, quality of life.

\section{Introduction}

The treatment of cancer in general and particularly of breast cancer is provided by a multidisciplinary team consisting of: medical oncologist, surgical oncologist, radiotherapist, oncology nurse, psychologist, nutritionist and physiotherapist.

Cancer treatment has a high impact on patients' quality of life, affecting life at all levels: physical, sensory, cognitive, psychological, social and spiritual. Rehabilitation is an important part of breast cancer care and is recognised as part of the complex oncological treatment plan. It aims to minimise the impact of oncological treatment for breast cancer and to help improve the quality of life of these patients (Taylor et al., 2006).

Ipsilateral arm lymphoedema is the most frequent long-term complication due to breast cancer surgery, chemo- and radiotherapy, affecting approximately $40 \%$ of women treated for breast cancer. Mastectomy is usually followed by axillary lymph node dissection as part of the oncological treatment plan. Consequently, the lymphatic drainage of the upper limb is partially obstructed and could be followed by arm lymphoedema. Upper limb lymphoedema 
is clinically obvious, is expressed by an increase in arm volume due to lymph retention and can result in disfigurement, physical discomfort, functional impairment, arm swallowing, pain and inflammatory symptoms. Anxiety, depression and emotional distress are more common in patients with secondary arm lymphoedema. This can also undermine body image and self-esteem. (Clark et al., 2005)

Any woman experiencing breast cancer trauma may need a personal physiotherapy programme to prevent and treat arm lymphoedema (Engrich, 2019).

\section{Methodology}

We carried out a retrospective study in order to assess the efficiency of physiotherapy procedures in reducing arm lymphoedema in women who underwent an exhaustive treatment plan for breast cancer (Figure 1).

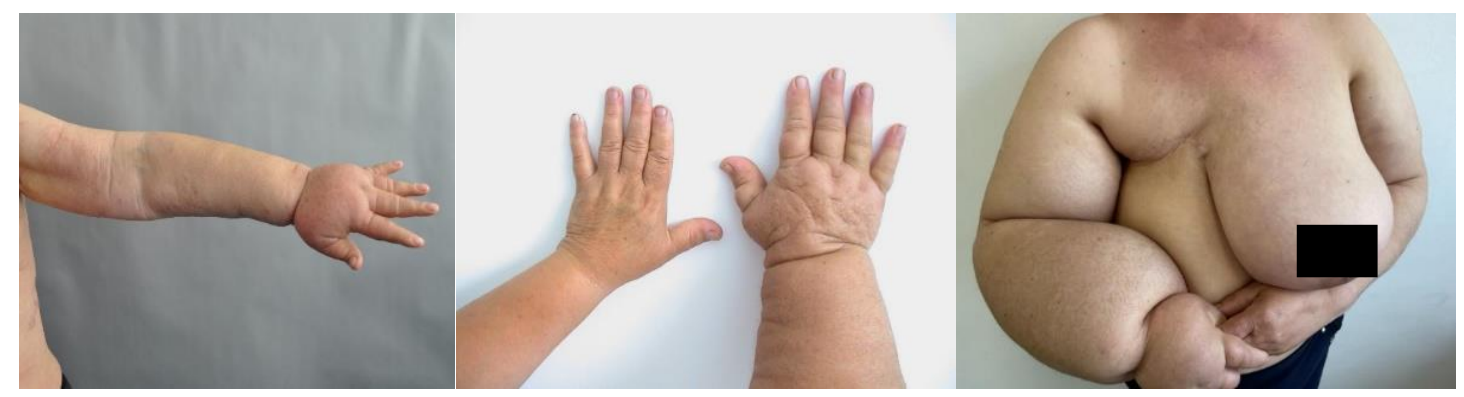

Figure 1. Arm lymphoedema associated with breast cancer

The study included 32 patients out of the 641 with breast cancer, who were treated by the same multidisciplinary team at the "Prof. Dr. Alexandru Trestioreanu" Institute of Oncology in Bucharest. They underwent unilateral modified radical mastectomy with axillary clearance between 1 January 2016 and 31 December 2019 due to developing ipsilateral arm lymphoedema, stage 2. All patients benefitted from six cycles of systemic neoadjuvant chemotherapy. None of the patients had preoperatory radiotherapy, and 9 patients needed adjuvant (postoperative) radiotherapy.

Of the 32 patients, 18 received individual counselling and education, manual lymph drainage techniques and compressive bandage. The remaining 14 patients associated the above-mentioned procedures but also benefitted from additional individual physiotherapy including stretching exercises (for the levator scapulae, trapezius and pectoralis major and minor muscles) and progressive active and action-assisted shoulder exercises.

Arm lymphoedema was assessed by comparative measurements of the circumference of both upper limbs using a retractable measuring tape (Figure 2). The measurements were carried out for both the arm and forearm by the same person, before and after the physiotherapy programme. A personal record was kept for each patient (Buzea \& Ancuța, 2018). 


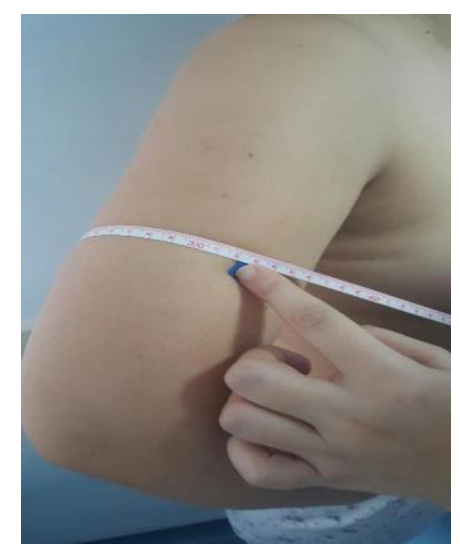

Figure 2. Measurement of arm circumference

We analysed the impact of other risk factors such as radiotherapy, body mass index (BMI), urban and rural impairments and dominant limb on the occurrence of ipsilateral arm lymphoedema.

Patients were scheduled for follow-up visits 1 and 3 months after treatment.

The same protocol for assessing the development of upper limb lymphoedema was carried out. Arm lymphoedema was considered when a difference of $2 \mathrm{~cm}$ between the upper arms or forearms was encountered (Petrek \& Heelan, 1998).

In the absence of a standard classification system, the rates for secondary lymphoedema range from $5 \%$ to $25 \%$. We used the classification of the European Society of Medical Oncology (ESMO-ESO) (Paluch-Shimon et al., 2017), specifying the stages of arm lymphoedema (Engrich, 2019):

1. Stage 0 (subclinical or latent): no clinical signs of lymphoedema, slight physical impairments.

2. Stage 1 (incipient): the hand, forearm and arm may be slightly swollen due to lack of protein-enriched lymphatic drainage; this stage is considered to be reversible as the skin and tissues have not been permanently affected.

3. Stage 2 (moderate): the upper limb appears clinically swollen, and the vertical positioning of the arm no longer reduces the oedema.

4. Stage 3 (severe): the upper limb is deformed and the skin is affected (Ridner, 2006).

Patients were informed and trained on the preventive and protective measures against the onset and progression of upper arm lymphoedema:

- Any systemic treatment, blood sampling or blood pressure measurement should be performed on the contralateral arm.

- Intense and challenging physical exertion as well as lifting weights should be avoided with the ipsilateral arm.

- Preventing ipsilateral arm infection.

- Avoiding trauma and injury.

- Healthy, low-salt diet and proper weight control.

- Avoiding extreme temperatures such as sauna and iced bandages.

- Recommended sports: swimming, walking and specific medical exercises. Overloading the upper limb during practice should be avoided. 
- Immediate physical examination in case of any signs of infection: erythema, pain, local swelling and fever. (Runowick, 1998; Koak \& Overgaard, 2000; Ferrandez \& Serin, 2006; Bloomquist et al., 2018)

The special techniques of manual lymphatic massage for the upper limb used to increase the cell oxygen levels lead to increased lymph drainage, which can significantly reduce the circumference of the affected arm. Lymphatic drainage massage should be gentle and performed through special manoeuvres that help improve the lymphatic flow. Manual lymphatic drainage follows a specific pathway, taking into account the anatomical and physiological features of the lymphatic system and aiming to open the lymphatic anastomosis and accessory drainage pathways (Engrich, 2019). Each lymphatic drainage movement should be performed 10 to 15 times with a duration of 2 seconds (Profir, 2016).

The most important contraindications to manual lymphatic drainage are represented by heart failure, acute arm swelling, hyperthyroidism, dermatological and infectious diseases and progressive oncological lesions (Singh et al., 2016; Stefani et al., 2017).

Another essential component in the management and treatment of post-mastectomy arm lymphoedema is the compressive bandage (Popescu, 2010; Constantin, 2011; Mateescu, 2014; Drăgan \& Pădure, 2018). The therapeutic effects targeted by the compressive bandage are to protect the skin from irritation and increase efficiency of the muscle pump mechanism, thus allowing higher pressure during muscle contraction and lower pressure during rest, which facilitates lymphatic drainage and prevents constriction.

The individualised postoperative physiotherapy procedure should not be difficult to perform and should aim at the upper limb movements to the limit of pain. It is important to increase the range of motion from one exercise to another, even by only a few degrees. When establishing an individualised physiotherapy treatment plan, we should take into consideration the lymphoedema stage, the time elapsed after surgery but also the age and characteristics of the patient (Todd et al., 2008).

The most commonly affected muscles after modified radical mastectomy with axillary clearance or radiotherapy are the pectoralis minor and major (affecting the pectoral pedicle), the subscapular muscle (affecting the subscapular pedicle) as well as the serratus and intercostal muscles (affecting the long thoracic pedicle - Charles-Bell). The impairment of the scapulohumeral joint occurs through poor postural behaviour, which is often due to pain or as a psychological reaction after surgery.

Therefore, patients with breast cancer can perform a moderate number of exercises in complete safety (Segal et al., 2017; Zuther, 2017).

The Canadian Society for Exercise Physiology and the American College of Sports Medicine (Buchan et al., 2016) recommend some basic guidelines such as:

- Each session should include warm-up and recovery after exercise.

- The goal of performing moderate-intensity aerobic exercise and also exercises to increase endurance should be set twice a week.

- Exercises aimed at increasing endurance should involve large muscle groups and should be performed 2 or 3 times a week (8-10 muscle groups, 8-10 repetitions, 2 sets).

- Weekly lymphatic drainage should be performed to improve lymphatic circulation. 
Complete decongestive therapy is the gold standard in lymphoedema management (Földi \& Strössenreuther, 2005; Profir, 2016; Racoviță, 2017; Engrich, 2019). This is an intensive therapeutic programme consisting of two phases, an intensive one (manual lymphatic drainage, multilayer bandage, physical exercise and skin care), and a maintenance one (selflymphatic drainage, elastic sleeve and BMI control) (De Joachim, 2005; Albu et al., 2012).

\section{Results}

In our study, the incidence rate of ipsilateral upper arm lymphoedema after mastectomy was $4.99 \%$ (32 out of the 641 patients) (Figure 3).

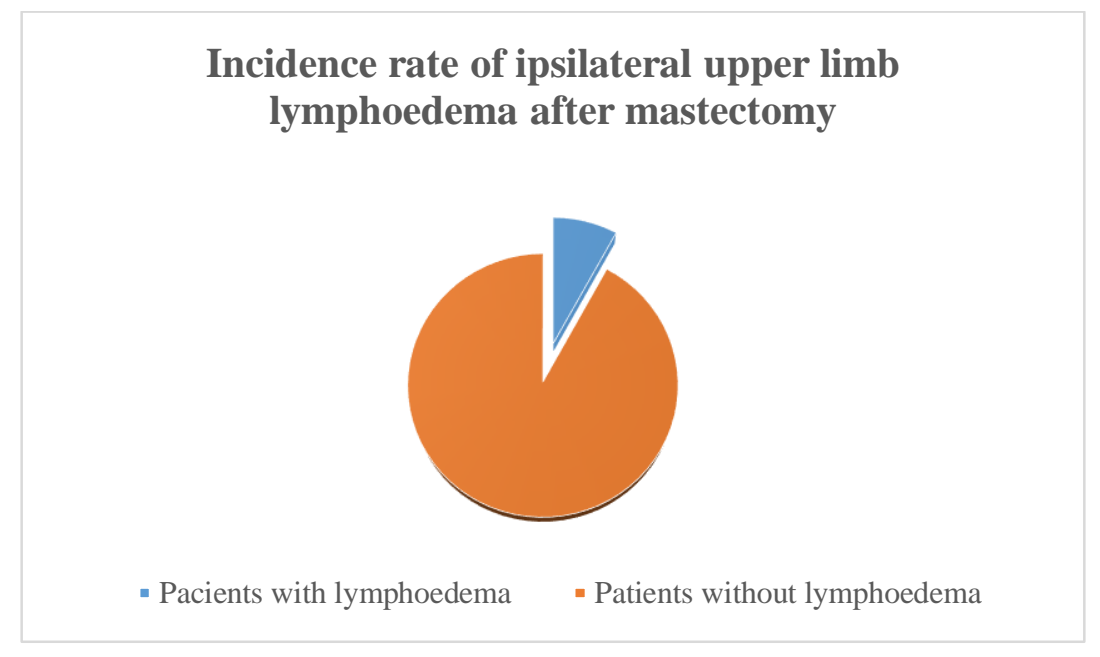

Figure 3. Incidence rate of ipsilateral upper limb lymphoedema after mastectomy

The study group included patients aged between 27 and 73 years. Two age subgroups were highlighted by a greater number of cases: 41-50 years and 51-60 years accounting for $28.1 \%$ (9 patients) and 34.3\% (11 patients), respectively, of the investigated participants (Figure 4).

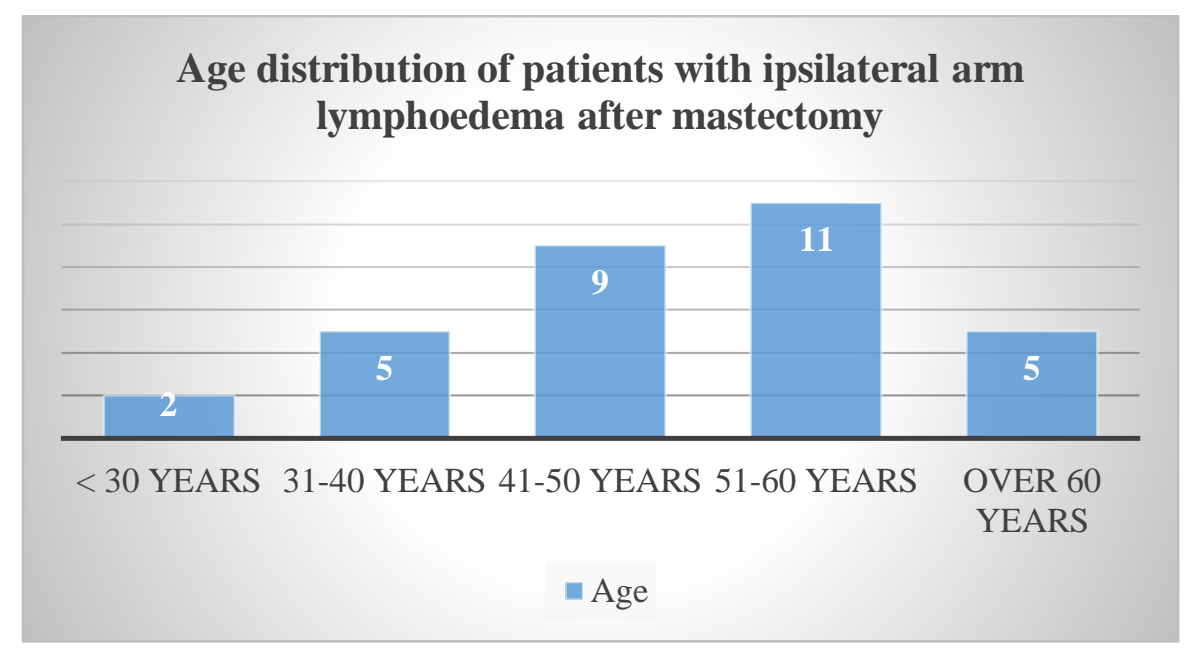

Figure 4. Age distribution of patients with ipsilateral arm lymphoedema after mastectomy 
The Body Mass Index revealed that 22 patients (68.75\%) with arm lymphoedema were overweight or obese, with a BMI over 27 (Figure 5).

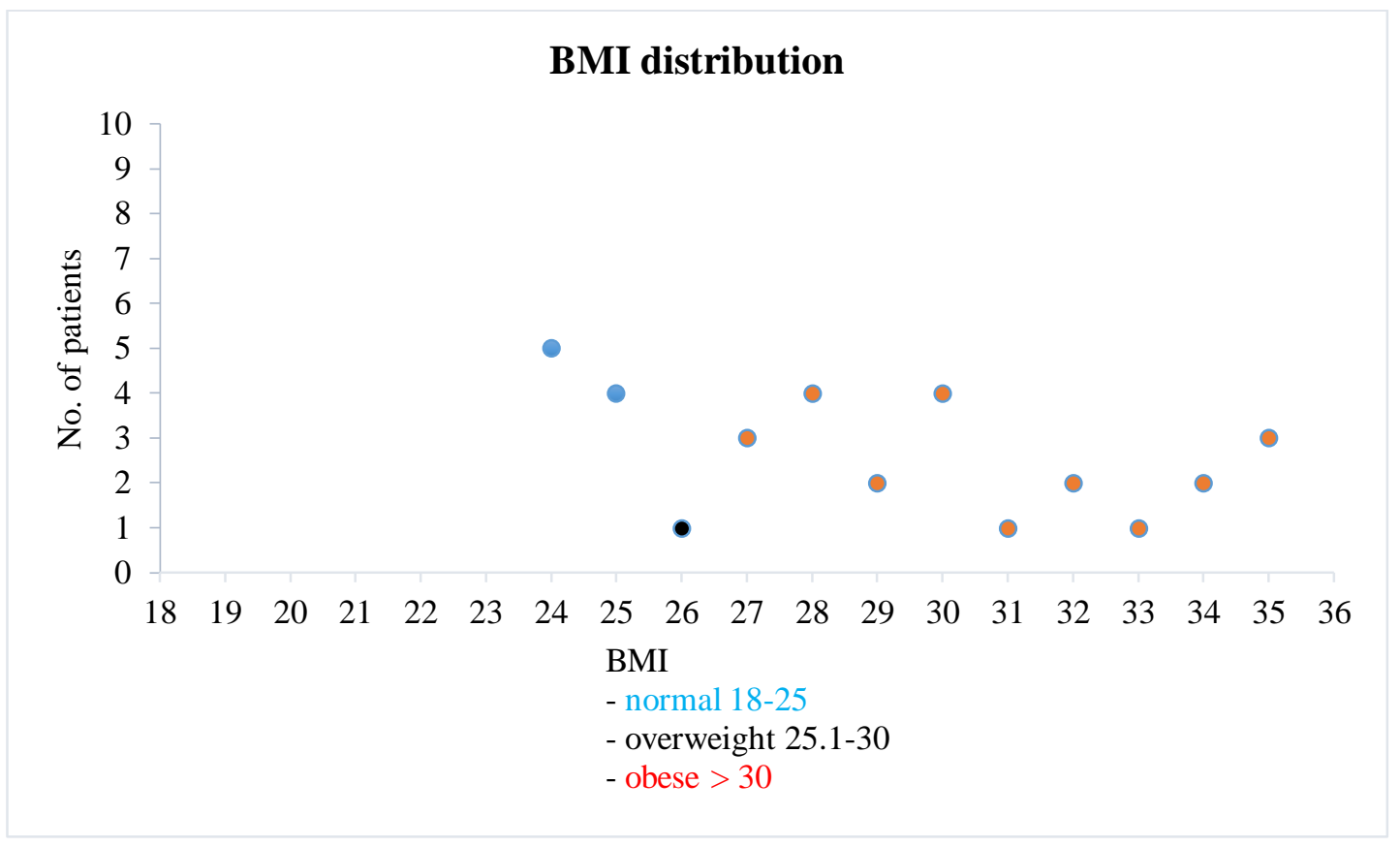

Figure 5. BMI for the study group

Approximately $2 / 3$ of patients (19 in number, 59.82\%) resided in urban areas and only 13 patients lived in rural areas (40.18\%). All 32 patients had breast cancer and were operated on the same site as the dominant upper limb.

Of the 18 patients who received individual counselling and education, manual lymph drainage and compressive bandage, 10 (55.5\%) decreased arm lymphoedema from stage 2 to 1 after 3 months of treatment.

Of the 14 patients who associated the aforementioned procedures and also benefitted from additional individual physiotherapy including stretching exercises (for the levator scapulae muscle, trapezius muscle, pectoralis major and minor muscles) and progressive active and action-assisted shoulder exercises, $11(78.5 \%)$ reduced arm lymphoedema to stage 1 and regained upper arm mobility and sensitivity. Only 1 patient $(7.14 \%)$ had a complete clinical treatment response to stage 0 lymphoedema. (Table 1)

Table 1. Characteristics of patients included in the studied group

\begin{tabular}{lcc}
\hline & $\begin{array}{c}\text { Patients who received only } \\
\text { counselling, manual lymph drainage } \\
\text { and compressive bandage }\end{array}$ & $\begin{array}{c}\text { Patients who received counselling, manual } \\
\text { lymph drainage and compressive bandage } \\
\text { but also additional physiotherapy }\end{array}$ \\
\hline $\begin{array}{l}\text { Patients who } \\
\text { responded to treatment }\end{array}$ & $10(55.5 \%)$ & $12(85.6 \%)$ \\
$\begin{array}{l}\text { Patients who did not } \\
\text { respond to treatment }\end{array}$ & $8(44.5 \%)$ & $2(14.4 \%)$ \\
Total no. of patients & 18 & 32 \\
\hline
\end{tabular}




\section{Discussion}

Arm lymphoedema is considered to be a chronic disease involving the abnormal swelling of the superficial tissues. It appears as a consequence of the lymphatic vessels' inability to drain the lymph after the lymph node clearance (Mortimer et al., 1996).

The lymphatic system is part of the circulatory system and consists of a network of vessels branched throughout the body, the smallest ones being located in the skin (lymphatic capillaries). Lymph nodes are spread along the route of the lymphatic vessels and are important filtration stations of infectious agents. Nodes are gathered in groups in various regions of the body (axilla, groin, etc.). The lymph is a clear fluid that is found in the spaces between cells (interstitial lymph) and flows towards the lymphatic channels (vascular lymph).

The role of the lymphatic system is complex, including the cleaning and filtration of toxins and microbial agents, immunity through lymph nodes, transport of vitamins, hormones, enzymes and, last but not least, the prevention of excessive fluid accumulation in tissues (Newton 2019).

The factors that can influence the upper arm lymphoedema after mastectomy are the number of removed lymph nodes, radiotherapy, wound infection and obesity (Mortimer et al., 1996; Coen et al., 2003; McTiernan, 2005; Cojocaru, 2014; Johansson et al., 2002; Nardone et al., 2005; Bani et al., 2007; Dieli-Cowright et al., 2018).

Patients with lymphedema have a higher risk of developing infections (Johansson et al., 2002), which may have different aetiologies: fungal infection - moisture can accumulate in the skinfolds due to perspiration, which can lead to lesions of the skin and thus its infection; bacterial infection - superficial infection of the skin (which is commonly caused by the betahaemolytic streptococcus); cellulite - deep infection of the dermis and subcutaneous fat.

A direct correlation between the extension of axillary clearance and the appearance of arm lymphoedema has been recorded (Barranger et al., 2005):

- the rate of lymphoedema after complete axillary dissection is about $10-15 \%$;

- the rate of lymphoedema after inferior axillary dissection is 6-9\%;

- the rate of lymphoedema after sentinel node biopsy is $1-5 \%$.

Arm lymphoedema occurs immediately after the completion of oncological treatments or even after a few years. According to the National Institute of Health of the United States, about $40 \%$ of women with breast cancer develop arm lymphoedema throughput their lives (Kissin et al., 1996; Runowick, 1998; Mansel et al., 2006; Morishita \& Tsubaki, 2017).

The Exercise Medicine Research Institute in the United States conducted a meta-analysis of 26 studies on specific mortality in breast, prostate and colorectal cancers, the result being an average decrease of $37 \%$ in specific mortality for patients undergoing an exercise programme (Chen et al., 2008). A reduction in specific mortality was also observed in patients with recurrent tumours enrolled in a physical rehabilitation programme (Van Waart et al., 2015).

Segal et al. (2017) published the article "Exercise for People with Cancer: A Clinical Practice Guideline" in the Journal of Current Oncology Practice. In order to develop these guidelines, the above authors gathered information from three guides with 18 reviews and 29 randomised studies. The resulting guidelines contain recommendations on the duration, frequency and intensity of exercise for cancer patients. 
The conclusion is that there is sufficient evidence to show the benefits of physiotherapy in oncology both during and after the disease (Ferrandez \& Serin, 2006; Lacomba et al., 2010).

\section{Conclusion}

Early initiation of physiotherapy after modified radical mastectomy with axillary lymph node dissection, along with patient education, is associated with a higher regression rate of arm lymphoedema compared to only patient education and awareness.

The treatment response rate was $85.7 \%$ in patients who benefitted from lymphatic drainage, compressive bandage and an individual physiotherapy plan compared to $55.5 \%$ in patients who only benefitted from lymphatic drainage and compressive bandage.

The factors that can influence the upper arm lymphoedema after mastectomy are the number of removed lymph nodes, radiotherapy, wound infection and obesity.

In the current context of the global spread of SARS-CoV-2, the online environment could be a feasible solution for continuing physiotherapy sessions in order to reduce symptoms and improve the quality of life of patients with cancer.

\section{Authors' Contribution}

All authors have equally contributed to this study and should be considered as main authors.

\section{References}

Albu, C., Albu, M. C., \& Armbruster, T. L. (2012). Kinetoterapie: Metodologia poziționării şi mobilizării pacientului [Physical therapy: The methodology of patient positioning and mobilisation]. Polirom.

Bani, H. A., Fasching, P. A., Lux, M. M., Rauh, C., Willner, M., Eder, I.,, Loehberg, C., Schrauder, M., Beckmann, M. W., \& Bani, M. R. (2007). Lymphedema in breast cancer survivors: Assessment and information provision in a specialized breast unit. Patient Education and Counseling, 66(3), 311-318. https://doi.org/10.1016/j.pec.2007.01.004

Barranger, E., Dubernard, G., Fleurence, J., Antoine, M., Darai, E., \& Uzan, S. (2005). Subjective morbidity and quality of life after sentinel node biopsy and axillary lymph node dissection for breast cancer. Journal of Surgical Oncology, 92(1), 17-22. https://doi.org/10.1002/jso.20343

Buzea, L., \& Ancuța, C. (2018). Algoritm clinic pentru îngrijirea limfedemului [Clinical algorithm for lymphedema care]. A XV-a Ediţie a Conferinței Naţionale „Îngrijirile de sănătate de la practică la cercetare", 13-14 septembrie 2018, Brașov. https://www.anip.ro/media/2014/08/ARO11_Algoritm-ingrijire-limfedem_Buzea.pdf

Bloomquist, K., Oturai, P., Steele, M. L., Adamsen, L., Møller, T., Christensen, K. B., Ejlrtdtrn, B., \& Hayes, S. C. (2018). Heavy-load lifting: Acute response in breast cancer survivors at risk for lymphedema. Medicine \& Science in Sports \& Exercise, 50(2), 187195. https://doi.org/10.1249/mss.0000000000001443

Buchan, J., Janda, M., Box, R., Schmitz, K., \& Hayes, S. (2016). A randomized trial on the effect of exercise mode on breast cancer-related lymphedema. Medicine \& Science in Sports \& Exercise, 48(10), 1866-1874. https://doi.org/10.1249/mss.0000000000000988 
Chen, Y.-W., Tsai, H.-J., Hung, H.-C., \& Tsauo, J.-Y. (2008). Reliability study of measurements for lymphedema in breast cancer patients. American Journal of Physical Medicine \& Rehabilitation, 87(1), 33-38. https://doi.org/10.1097/phm.0b013e31815b6199

Clark, B., Sitzia, J., \& Harlow, W. (2005). Incidence and risk of arm oedema following treatment for breast cancer: A three-year follow-up study. QJM: An International Journal of Medicine, 98(5), 343-348. https://doi.org/10.1093/qjmed/hci053

Coen, J. J., Taghian, A. G., Kachnic, L. A., Assaad, S. I., \& Powel, S. N. (2003). Risk of lymphedema after regional nodal irradiation with breast conservation therapy. International Journal of Radiation Oncology, Biology, Physics, 55(5), 1209-1215. https://doi.org/10.1016/s0360-3016(02)04273-6

Cojocaru, I.-V. (2014). Recuperarea medicală în oncologie [Medical rehabilitation in oncology]. https://nutricor.ro/index.php/recuperarea-medicala-in-oncologie/

Constantin, M. (2011). Tehnici de manevrare a bolnavului [Patient handling techniques]. Universitatea Oradea, Facultatea de Educație Fizică și Sport, Kinetoterapie și Motricitate Specială.

De Joachim, E. (2005). Lymphedema management: The comprehensive guide for practitioners. Thieme.

Dieli-Conwright, C. M., Courneya, K. S., Demark-Wahnefried, W., Sami, N., Lee, K., Buchanan, C. A., Spicer, D. V., Tripathy, D., Bernstein, L., \& Mortimer, J. E. (2018). Effects of aerobic and resistance exercise on metabolic syndrome, sarcopenic obesity, and circulating biomarkers in overweight or obese survivors of breast cancer: A randomized controlled trial. Journal of Clinical Oncology, 36(9), 875-883. https://doi.org/10.1200/jco.2017.75.7526

Drăgan, C. F., \& Pădure, L. (2018). Metodologie și tehnici de kinetoterapie [Methodology and kinesiotherapy techniques]. Editura Naţional.

Engrich, E. (2019). Kinetoterapia pe îțelesul tuturor [Kinesiotherapy for everyone to understand]. Editura Medicală.

Ferrandez, J., \& Serin, D. (2006). Rééducation et cancer de sein [Rehabilitation and breast cancer]. Elsevier Masson SAS.

Földi, M., \& Strössenreuther, R. (2005). Principes du drainage lymphatique [Principles of lymphatic drainage]. Maloine.

Johansson, K., Ohlsson, K., Ingvar, C., Albertsson, M., \& Ekdahl. C. (2002). Factors associated with the development of arm lymphedema following breast cancer treatment: A match pair case-control study. Lymphology, 35(2), 59-71. PMID: 12081053

Koak, Z., \& Overgaard, J. (2000). Risk factors of arm lymphedema in breast cancer patients. Acta Oncologica, 39(3), 389-392. https://doi.org/10.1080/028418600750013168

Kissin, M. W., Querci della Rovere, G., Easton, D., \& Westbury, G. (1986). Risk of lymphoedema following the treatment of breast cancer. British Journal of Surgery, 73(7), 580-584. https://doi.org/10.1002/bjs.1800730723

Lacomba, M. T., Yuste Sanchez, M. J., Zapico Goñi, A., Merino, D. P., Mayoral del Moral, O., Cerezo Téllez, E., \& Minayo Mogollón, E. (2010). Effectiveness of early physiotherapy to prevent lymphoedema after surgery for breast cancer: Randomized, single blinded, clinical trial. BMJ, 340. https://doi.org/10.1136/bmj.b5396

Mansel, R. E., Fallowfield, L., Kissin, M., Goyal, A., Newcombe, R. G., Dixon, J. M., Yiangou, C., Horgan, K., Bundred, N., Monypenny, I., England, D., Sibbering, M., Abdullah, T. I., Barr, L., Chetty, U., Sinnett, D. H., Fleissig, A., Clarke, D., \& Ell, P. J. (2006). Randomized multicenter trial of sentinel node biopsy versus standard axillary treatment in operable breast cancer: The ALMANAC Trial. Journal of the National Cancer Institute, 98(9), 599-609. https://doi.org/10.1093/jnci/djj158 
Mateescu, D. (2014). Concepte actuale de îngrijire a pacientului oncologic și noi metode terapeutice. Ghidul pacientului oncologic [Current concepts of oncology patient care and new therapeutic methods. A guide for the oncology patient]. Benett.

McTiernan, A. (2005). Obesity and cancer: The risks, science, and potential management strategies. Oncology, 19(7), 871-881. PMID: 16053036

Mortimer, P. S., Bates, D. O., Brassington, H. D., Stanton, A. W. B., Strachan, D. P., \& Levick, J. R. (1996) The prevalence of arm oedema following treatment for breast cancer. QJM: An International Journal of Medicine, 89(5), 377-380. https://doi.org/10.1093/qjimed/89.5.377

Nardone, L., Palazzoni, G., D’Angelo, E., Deodato, F., Gambacorta, M. A., Micciche, F., \& Morganti, A. G. (2005). Impact of dose and volume on lymphedema. Rays, 30(2), 149155. PMID: 16295908

Newton, R. (2019). Exercise medicine for cancer management. Exercise Medicine Research Institute, Australia. https://www.cancerwa.asn.au/resources/2017-04-04-Exercise-Medicine-Newton.pdf

Paluch-Shimon, S., Pagani, O., Partridge, A. H., Abulkhair. O., Cardoso. M.-J., Dent, R. A., Gelmon, K., Gentilini, O., Harbeck, N., Margulies, A., Meirow, D., Pruneri, G., Senkus, E., Spanic, T., Sutliff, M., Travado, L., Peccatori, F., \& Cardoso, F. (2017). ESOESMO 3rd International Consensus Guidelines for Breast Cancer in Young Women (BCY3). The Breast, 35, 203-217. https://doi.org/10.1016/j.breast.2017.07.017

Petrek, J. A., \& Heelan, M. C. (1998). Incidence of breast carcinoma-related lymphedema. Cancer, 83(12 Suppl American), 2776-2781. https://doi.org/10.1002/(sici)1097-0142(19981215)83:12b+\%3C2776::aidcncr25\%3E3.0.c0;2-v

Popescu, R. (2010). Recuperarea membrului superior ortezat și protezat [Rehabilitation of the orthotic and prosthetic upper limb]. Editura Medicală Universitară.

Profir, D. (2016). Limfedemul: Indicație principală pentru drenajul limfatic cu ajutorul aparatului BTL-6000 Lymphostym 12 Easy [Lymphedema: The main indication for lymphatic drainage using the BTL-6000 Lymphostym 12 Easy]. Revista de Balneologie, 4, 22-25.

Racoviță, B. (2017, 17 martie). Kinetoterapia pentru limfedemul postmastectomie [Physical therapy for the upper limb lymphoedema after mastectomy]. Viața Medicală. https://www.viata-medicala.ro/na/kinetoterapia-pentru-limfedemul-postmastectomie12973

Ridner, S. H. (2006). Pretreatment lymphedema education and identified educational resources in breast cancer patients. Patient Education and Counseling, 61(1), 72-79. https://doi.org/10.1016/j.pec.2005.02.009

Runowick, C. D. (1998). Lymphedema: Patient and provider education. Current status and future trends. Cancer, 83(12 Suppl American), 2874-2876.

https://doi.org/10.1002/(SICI)1097-0142(19981215)83:12B+\%3C2874::AIDCNCR42\%3E3.0.CO;2-4

Segal, R., Zwaal, C., Green, E., Tomasone, J. R., Loblaw, A., Petrella, T., \& The Exercise for People with Cancer Guideline Development Group. (2017). Exercise for people with cancer: A clinical practice guideline. Current Oncology, 24(1), 40-46.

https://doi.org/10.3747/co.24.3376

Singh, B., DiSipio, T., Peake, J., \& Hayes, S. C. (2016). Systematic review and meta-analysis of the effects of exercise for those with cancer-related lymphoedema. Archives of Physical Medicine and Rehabilitation, 97(2), 302-315. https://doi.org/10.1016/j.apmr.2015.09.012

Morishita, S., \& Tsubaki, A. (2017). Physical therapy in patients with cancer. In T. Suzuki (Ed.), Clinical physical therapy (Chapter 6, pp. 95-120). DOI: 10.5772/65235 
Stefani, L., Galanti, G., \& Klika, R. (2017). Clinical implementation of exercise guidelines for cancer patients: Adaptation of ACSM's guidelines to the Italian model. Journal of Functional Morphology and Kinesiology, 2(1): 4. https://doi.org/10.3390/jfmk2010004

Taylor, R., Jayasingue, U. W., Koelmeyer, L., Ung, O., \& Boyages, J. (2006). Reliability and validity of arm volume measurements for assessment of lymphoedema. Physical Therapy, 86(2), 205-214. PMID: 16445334

Todd, J., Scally, A., Dodwell, D., Horgaan, K., \& Topping, A. (2008). A randomised controlled trial of two programmes of shoulder exercise following axillary lymph node dissection for invasive breast cancer. Physiotherapy, 94(4), 265-273. https://doi.org/10.1016/j.physio.2008.09.005

Van Waart, H., Stuiver, M. M., van Harten, W. H., Geleijn, E., Kieffer, J. M., Buffart, L. M., de Maaker-Berkhof, M., Boven, E., Schrama, J., Geenen, M. M., Meerum Terwogt, J. M., van Bochove, A., Lustig, V., van den Heiligenberg, S. M., Smorenburg, C. H., Hellendoorn-van Vreeswijk, J. A. J. H., Sonke, G. S., \& Aaronson, N. K. (2015). Effect of low-intensity physical activity and moderate- to high-intensity physical exercise during adjuvant chemotherapy on physical fitness, fatigue, and chemotherapy completion rates: Results of the PACES randomized clinical trial. Journal of Clinical Oncology, 33(17), 1918-1927. https://doi.org/10.1200/jco.2014.59.1081 